\title{
Corrado Alvaro and the Calabrian mafia: a critical case study of the use of literary and journalistic texts in research on Italian organized crime
}

\author{
Amber Phillips ${ }^{1}$ (ID \\ Published online: 11 July 2016 \\ (C) The Author(s) 2016. This article is published with open access at Springerlink.com
}

\begin{abstract}
The Calabrian mafia, or 'Ndrangheta, is a hugely powerful international crime syndicate, with origins that can be traced back to the late nineteenth century. By far the least studied of Italy's 'big three' mafias, socio-historical research on the earlier stage of the organisation's history has tended to make extensive use of literary and journalistic texts as source material (see Arlacchi (1983); Ciconte (1992); Paoli (2003)). This paper will present a cautionary example of the importance of interrogating literary and journalistic representations of Italian organized crime sensitively and within context, taking an article written by celebrated Calabrian writer Corrado Alvaro as a case study. It argues that academic perceptions of the early 'Ndrangheta are, through their reliance on cultural products, impacted by the narratives contained within such texts; a phenomenon which merits further investigation. Further, drawing on cultural memory studies, it argues that, while the accuracy of the representations of the 'Ndrangheta contained within these texts may be called into question, they do, through their ability to both reflect and shape public opinion, have a valuable contribution to make to our understanding of perceptions of Calabrian organized crime in its native region.
\end{abstract}

Keywords 'Ndrangheta $\cdot$ Calabria $\cdot$ Mafia $\cdot$ Italian organised crime $\cdot$ Cultural representations $\cdot$ Perception $\cdot$ Media representation $\cdot$ Cultural memory $\cdot$ Press

\section{Introduction}

Despite being recognized as one of the world's most powerful criminal organizations (Europol 2013), with origins that can be traced back to the late nineteenth century, the

Amber Phillips

Amber.Phillips@ bristol.ac.uk

1 University of Bristol, Bristol, UK 
Calabrian mafia, or 'Ndrangheta, has only in the last few decades begun to draw substantial attention from the scholarly community. Much like the remote, economically depressed Italian region that produced it, this mafia has been ignored by government and media alike for much of its history, with the bulk of attention being devoted instead to its Sicilian cousin, Cosa Nostra. ${ }^{1}$ Of course, the 'Ndrangheta did not emerge fully formed in the $1880 \mathrm{~s}$, and it is generally agreed upon by scholars that around the mid-twentieth century the organisation began to undergo a kind of transformation, aggressively expanding its areas of activity and taking ruthless advantage of opportunities offered by Italy's economic miracle (Ciconte 1992, 298). Since it remained under-noticed and under-researched for decades even after this boom in activity, it is perhaps unsurprising that research on the earlier phase of its history has so far been relatively scarce; Calabria's remoteness and marginality, an exceptionally high illiteracy rate, and the inherently secretive nature of the organization itself all pose unique challenges to the researcher hunting for material.

Perhaps partly for this reason, historical and sociological research on the pre-1950s 'Ndrangheta has tended to make use of an unusual combination of sources. Literary and journalistic texts, including newspaper articles, novels, and short stories, are frequently interspersed with the more traditional mainstays of the social historian (i.e. court and police archives). Unfortunately, however - with the notable exception of recent work by John Dickie $(2012,2013)$ and Fabio Truzzolillo (2013) - these literary and journalistic texts are very often cited with little to no acknowledgment of their provenance or genre, nor of the presence (or potential impact) of an authorial voice or agenda. ${ }^{2}$ As Shaw has noted, although historians have, since Hayden White, increasingly recognised 'the centrality of the role of the author in imposing a, sometimes artificial, narrative on real life events' - something which, as Lupo (1993, 31) observes, must also be applied to judicial documents in the field of mafia studies attention should be 'extended to the role of the literary author in their shaping of historical fiction', 3 particularly given 'the authority of the literary form in the re-writing of history' (Shaw 2012, 146;7). While the link between historical fiction and journalistic texts may appear obscure at this stage, as will become clear, in the case of representations of the 'Ndrangheta's past, the literary form is both prevalent and influential, and there are numerous significant parallels to be drawn.

Recent studies of media representations of organised crime (Di Ronco and Lavorgna 2016) have rightly stressed the significance of the impact of the perceptions and narratives they present on both policy-makers and the public, and also noted that these narratives 'may not fully correspond' with 'current academic views on Organised Crime' (Ibid.,2). However, the ability of media representations (and other cultural representations of the phenomenon, including literature) to interact with, and to influence, academic perceptions of OC, remains under-explored, particularly with regard to history. Drawing on cultural memory studies, this paper will assert that literary and journalistic representations of the early 'Ndrangheta act as what Welzer $(2010,287)$ refers to as a 'structuring matrix for the processing of information', forming part of a complex network of representations, which are capable of influencing one another. Academic perceptions of the 'Ndrangheta's history are, through their reliance on

\footnotetext{
${ }^{1}$ A thorough examination of the historiography of the 'Ndrangheta is provided by Truzzolillo (2011).

2 See, for example, Arlacchi (1983, 2010); Ciconte (1992); and Paoli (2003).

${ }^{3}$ Shaw is paraphrasing the work of Linda Hutcheon here.
} 
cultural products including literature and journalism, necessarily impacted by the narratives contained within such representations, and this phenomenon merits further investigation.

This paper will further argue that Italian journalistic representations of organised crime need to be treated particularly carefully, as such texts are subject to a number of culture-specific conventions which must affect our interpretation of their content: in this case, their portrayal of the characteristic nature of the early 'Ndrangheta. I will argue that the features of certain Italian journalistic texts mean that they should be considered as 'semi-literary', and as such, must be contextualised by an understanding not just of the individual writer's literary output, but also of the significance of literature as a conveyor and influencer of cultural attitudes. Neumann (2010) has highlighted the huge significance of literature as a carrier and influencer of widespread cultural attitudes to past events, while Erll $(2010,389)$ points to the power of fictional media to 'generate and mould images of the past which will be retained by whole generations.' A further consideration lies in the specificity of the Italian journalistic tradition, described by Murialdi as 'a journalism imbued with great literary traditions and strong political passions' as opposed to the Anglo-Saxon predilection for 'factual journalism' (Murialdi 1998, 13). ${ }^{4}$ This factor is worth pointing out even though the majority of historians and sociologists cited are of Italian origin, and are thus likely to be implicitly aware of it.

The case study taken for this article presents a cautionary example of the importance of interrogating literary and journalistic representations of the 'Ndrangheta sensitively, and within their cultural and historical context. While there is certainly no shortage of Calabrian writers whose work might be analysed to this end, ${ }^{5}$ I have selected Corrado Alvaro (1895-1956), due to his unique position among Calabrian writers in the Italian cultural imaginary. Arguably Calabria's most celebrated literary export, Alvaro is also becoming an increasingly frequent presence in discourse surrounding the anti-'Ndrangheta movement, quoted by bloggers, campaigners, and even in rap songs, as well as appearing in a number of books on the mafia. The most famous quotation attributed to the author has a particular resonance for the anti-mafia movement: 'the deepest despair that can take hold of a society is the fear that living honestly is futile' (Alvaro 1959, 8). ${ }^{6}$ However, this quotation is in itself a strong indicator of Alvaro's suitability as an exemplar of the misappropriation of cultural products: the author's original words have been subjected to a kind of Chinese-whispers effect, frequently misquoted, and retrospectively imbued with an anti-mafia sentiment which is not present in the original context (an isolated thought in a diary entry from 1948). ${ }^{7}$

\footnotetext{
4 "un giornalismo fattuale" and "un giornalismo che risente di grandi tradizioni letterarie e di forti passioni politiche" (Murialdi 1998, 13). All translations, unless otherwise stated, are my own.

${ }^{5}$ The novels of Calabrian writers Saverio Strati, Luca Asprea, and Saverio Montalto have all featured extensively in historical and sociological research on the early 'Ndrangheta. My current $\mathrm{PhD}$ thesis focuses in part on the interpretation of these texts by various different actors.

6 "La disperazione più grave che possa impadronirsi d'una società è il dubbio che vivere rettamente sia inutile." (Alvaro 1959, 8). This quotation features on the title pages of Gratteri and Nicaso $(2010,1)$, and Dickie (2013, v); and is misquoted by di Girolamo (2012, 209). It also features on the high- profile site Wikimafia.it http://www.wikimafia.it/la-ndrangheta-in-ottima-salute/ and Gustavo Gesualdo's 'Cittadino Antimafia', http://www.ilcittadinox.com/blog/cittadini-antimafia.html, as well as in the rap video Dalle mie parti, Loop Loona, November 2014.

${ }^{7}$ N.B. With regard to the misquoting of the author's original words, the word 'rettamente' has been changed to 'onestamente' in a number of cases.
} 
The central case study of my article is a piece written by Alvaro in 1955 for the Italian national newspaper Corriere della Sera. This piece has been referenced extensively by 'Ndrangheta scholars over the last few decades as an authoritative, first-hand description of the organization, and as a source it is frequently cited alongside police records and court documentation, as if to indicate that its content should be interpreted according to the same criteria (See: Ciconte 1992, 42, 57, 72, 214 and 221; Gratteri and Nicaso 2010, 22, 27; Gratteri and Nicaso 2012, 70; Paoli 2003, 183). While it is certainly not my intention to suggest that the representation of Italian organised crime in court documentation should ever be considered to be free of subjective bias (see Lupo 1993, 31) there is no question that the function, purpose, and audience of such documents are substantially different to those of journalistic and literary texts, and that where they are quoted alongside one another without distinction, the latter risk being interpreted as impersonal relayers of historical 'fact'. Few scholars who cite Alvaro's article consider the presence of a subjective narrative voice within the text, nor the potential for an authorial agenda - indeed, as the contemporary uses of the author's words indicate, he is rarely, if ever, assumed to be anything other than entirely critical of the mafia. Additionally, little rigour is generally applied to establishing the genre of 'La fibbia', particularly the literary nature of the text, nor of the potential of this to impact upon our understanding of the content. The crucial elements of memory and nostalgia are also ignored, though the text is rich with the author's personal recollections and, as Birgit Neumann $(2010,33)$ has observed, 'the rendering of memories potentially tells us more about the rememberer's present, his or her desire or denial, than about actual past events.'

In this paper, I offer a reading of Alvaro's article which challenges the prevailing contemporary perception of the author's attitude to the 'Ndrangheta, insisting that the genre and context of literary-journalistic sources are fundamental to our interpretation of their content. Informed by a number of other works by Alvaro, I argue that the text should not be cited uncritically as a source of socio-historical data on the "Ndrangheta, and that, in fact, one can raise substantial questions regarding the accuracy of the picture it paints of the organisation; a portrait which is distorted by sentiment and nostalgia, and which constructs an idealised vision of a 'traditional mafia' gradually supplanted by a more nefarious modern incarnation following the Second World War.

It should be noted that this separation between a traditional and a modern 'Ndrangheta complements the view of the organisation's development put forward by the sociologist Pino Arlacchi in the early 1980s (Arlacchi 1983), which itself draws substantially on views of the Sicilian mafia prevalent in the 1970s (Hess 1970; Blok 1974). Arlacchi identified two separate incarnations of the 'Ndrangheta phenomenon; an 'entrepreneurial mafia', which emerged in the post-war boom years, and, before it, a 'traditional mafia', which essentially represented a set of values and behaviours typical to the socio-economic conditions of certain areas of the region. According to Arlacchi, the 'Ndrangheta was not, and is not, a structured, formal criminal organization, and prior to the mid-twentieth century, it was a purely sociocultural phenomenon. This hypothesis has been convincingly overturned in recent years, particularly in light of Lupo's work on the Sicilian mafia (1992) and research by Dickie (2012) and Truzzolillo (2013), which has uncovered significant evidence of continuity in the organisation's hierarchy and structure from the late nineteenth century to the present day. 
However, the myth that the early 'Ndrangheta was essentially a loose band of individual delinquents rather than a hierarchical criminal organization, is a persistent one, and has a significance and impact which goes far further than the academic sphere. It both reflects and contributes to the historic tendency of the Italian government and media to profoundly underestimate the extent of organised criminality in Calabria - a tendency which has allowed it to thrive (Dickie 2013). Through careful analysis of the representation of the 'Ndrangheta's past in Alvaro's article, we can gain significant insight into the factors that have contributed to this tendency, and raise interesting questions regarding perceptions of the organisation in its native region (drawing parallels with the phenomenon of Sicilianismo in Sicily). ${ }^{8}$ Key to this is the understanding that 'media products do not just deliver versions of the past; they also determine the perception of the present' (Welzer 2010, 287).

\section{Introducing Corrado Alvaro}

It is necessary to begin by addressing exactly why Corrado Alvaro and his writing should be of such interest to researchers of the early "Ndrangheta. Alvaro was born in 1895 in the village of San Luca, a fact which straight away signals a strong potential connection with Calabrian organized crime. The name of this tiny mountain village has been synonymous with the 'Ndrangheta from the late nineteenth century right up to the present day - the Duisburg massacre in Germany in 2007 was the culmination of a blood feud that began in San Luca (Badolati 2014, 15). Just as important as his birthplace is Alvaro's rarity as a native Calabrian writer who rose to gain celebrated status at a national level in Italy. Although he spent most of his career living away from Calabria, Alvaro consistently referred back to it in his fiction and in his journalism, depicting scenes of traditional Calabrian peasant culture and frequently calling the Italian state to account for its neglect of the region. Dickie $(2013,83)$ has referred to him as 'the unofficial spokesman for the voiceless poor of his home region', and while it is important not to overstate his contemporary fame or influence, Alvaro does stand out as rare voice of informed authority on Calabrian organized crime at a crucial time in its history, making him an attractive potential source for scholars.

The article which forms the case study for this paper was published on 17 September 1955, a year which might be described as the watershed moment for national public awareness of Calabrian organized crime. ${ }^{9}$ The launch of the Marzano Operation, the first major national police crackdown on organized crime in Calabria, provoked an unprecedented clamour of press interest in the region, much of which was characterised by its use of well-established negative stereotypes of the South as lawless, savage, and backward. ${ }^{10}$ Alvaro's piece appeared in Italian national newspaper Corriere della Sera

\footnotetext{
${ }^{8}$ Sicilianismo refers to a cultural phenomenon defined by Farrell $(1995,32)$ as a 'complex of prejudices and attitudes' manifested as 'a hysterical rejection of all criticisms of Sicily, whether well founded and however motivated, as lèse-majesté'. With regard to the mafia, this involves either denying its existence outright, or interpreting anti-mafia measures as an attack on the region.

${ }^{9}$ For an in-depth analysis of the significance of 1955, see Dickie (2013, 67-91), and Ciconte (1992, 244-294). Both historians identify it as the first year in which Calabrian organized crime was meaningfully acknowledged and discussed on a national scale.

${ }^{10}$ The response of the national press to the Marzano Operation is outlined by Ciconte (1992, 287-288). For more on the tradition of negative stereotyping of the South in the Italian press, see Dickie (1999); Gribaudi (1996); Moe (2002).
} 
at the height of this media storm. Crucially, the text was published on the paper's terza pagina (page three), a space which in contemporary Italian publishing tradition was reserved for elite cultural personalities, literature (including racconti or short stories), opinion, and travel writing (Ceccuti 1978, 177). The location of the piece, and the high profile of its author, would immediately indicate a literary quality to the text to the contemporary reader; a significant contextual consideration which is unacknowledged by the vast majority of those who cite it in a historical or sociological capacity.

Its title is 'La fibbia' (literally translated as 'the buckle'), which is taken from a list of several different names for the Calabrian mafia in the opening sentence, alongside 'ndranghita' and 'Onorata Società' [honoured society]. In the text, Alvaro paints a picture of a mafia which has emerged as a result of the failure of the Italian state to impose any kind of order or justice, and which is deeply connected to the socioeconomic situation of the region. The personal memories and experiences of the author are a key element of the text, including details such as the typical behaviours and priorities of mafia affiliates and their particular taste in clothes. There is also an emphasis on the idea that la Fibbia or the mafia forms an accepted part of everyday life in Alvaro's native region, which the author illustrates in the first paragraph with a particularly striking recollection; arriving home for the (school?) holidays one day, his mother informs him that his father is upstairs with 'the people from the association' which she then clarifies to the confused Alvaro as 'the delinquent association' (i.e. the mafia). ${ }^{11}$ Alvaro is neither surprised nor frightened by this. He has known of the 'Ndrangheta, he claims, 'da quando ebbi l'età della ragione' - since he was old enough to understand.

Despite the longstanding familiarity with the 'Ndrangheta which the author declares in the article, however, few of the historians who reference 'La fibbia' acknowledge a curious fact: there seems to be considerable variation in scholarly opinion as to whether or not Alvaro mentioned the Calabrian mafia at all in any of his work prior to the publication of this article in 1955. Some, including Pasquino Crupi (1992) and Antonio Nicaso (2007) suggest that 'La fibbia' represents Alvaro's sole acknowledgment of the existence of the 'Ndrangheta in his entire forty-year writing career. Given the author's commitment to portraying the poverty and hardships suffered by the inhabitants of his native region, it is reasonable here to draw comparisons with the Sicilian context, and conclude that Alvaro was guilty of what Leonardo Sciascia saw as a kind of literary omertà among Sicilian realist writers; that is, a failure to confront the existence of the mafia (Farrell 1995, 14). ${ }^{12}$ Before pursuing this line of argument, however, it is vital to point out that the premise it rests on is contested; the sociologist Letizia Paoli (2003, 17) states that Alvaro mentioned the 'Ndrangheta in 'several short stories'. This very fundamental disagreement on such an apparently basic point should straight away raise some important questions for the researcher, and it is clear that the two positions cannot both be accurate. As it turns out, however, neither is strictly correct.

The two stories offered as examples by Paoli $(2003,256)$ in her bibliography actually contain no reference to the 'Ndrangheta, nor anything resembling a criminal

\footnotetext{
11 "quelli dell'associazione"; "l'associazione a delinquere" (Alvaro 1955a).

12 In Sciascia's view, influential Sicilian literary figures such as Giovanni Verga and Luigi Capuana had, despite their realist principles, 'collaborated in a conspiracy of silence which worked to the advantage of the mafia' (Farrell 1995, 14).
} 
organisation - and indeed, their dates of publication (1929 and 1930) would make them subject to the ban imposed by the fascist government in the late 1920s which forbade any mention of the mafia in print (Crupi 1992, 64). Crupi even uses the very same stories cited by Paoli as examples to support his explanation for Alvaro's failure to acknowledge the 'Ndrangheta in any of his work prior to 'La fibbia'. For Crupi, these stories are symptomatic of Alvaro's tendency to idealise and romanticize Calabrian peasant culture. Alvaro's failure to depict the mafia is, Crupi says, connected to the author's inability to distinguish between the values of the mafia, and the values of Calabrian traditional society; he cannot criticise one without criticising the other (Ibid., p.70). The comparison with the Sicilian context thus seems a sound one, particularly in light of one of the motives Farrell (1995) suggests for the reticence of the Sicilian realists to address the mafia in their work; a form of Sicilianismo, which rejected any representation of the mafia as a dangerous criminal phenomenon, in order to stave off prejudiced attacks on the region. This is manifested significantly in the work of nineteenth century folklorist Giuseppe Pitrè, who 'saw the essence of mafia conduct as a grand, Robin Hood resistance to bullying and oppression' (Farrell 1995, 18), situating it as part of the traditional culture of the region.

Crupi's theory is an interesting one, particularly in light of the fact that a number of scholars have identified the appropriation of traditional culture as a tactic historically employed by the 'Ndrangheta to build consensus in the communities in which it operates (Ciconte 1992, 77-78; Paoli 2003, 183-186). However, the premise which it rests on is unsound: the 'Ndrangheta is not entirely absent from Alvaro's work prior to 'La fibbia'. It is true, as far as my research has found, that Alvaro makes no reference to the 'Ndrangheta in any work published prior to 1955. It does, however, appear in a number of other articles published by the author in 1955, and in at least one short story from the same year, as Dickie $(2013,490)$ has pointed out, and as Crupi eventually briefly acknowledges (2013). ${ }^{13}$ As will become clear, despite the inaccuracy of his initial observation, Crupi's ideas can still be applied successfully to the analysis of Alvaro's other representations of the 'Ndrangheta. By analysing Alvaro's depiction of organised crime in a sample of these texts, we are able to gain a wider understanding of the context in which 'La fibbia' was written, opening the way to an interpretation which challenges the widely-held assumption that the author was entirely hostile to the 'Ndrangheta.

A good starting point for establishing context is the short story, 'Angelino', since, as will be explained, it contains many themes prevalent in Alvaro's previous literary portrayals of Calabria and its inhabitants. Published as part of a collection in 1955, and set just after the Second World War, the narrative describes the title character's return from the United States to his native village. Upon his return, word spreads in the village that Angelino was deported as a criminal, which leads to the young man being invited to join the 'onorata società' [honoured society], a common alternative term for the 'Ndrangheta:

\footnotetext{
${ }^{13}$ In this later, revised edition, Crupi briefly acknowledges the existence of the short story 'Angelino', but since the volume is more of an anthology than an analytical work, there is little space for him to amend his original analysis, and no additional thoughts are offered on the absence of the 'Ndrangheta from Alvaro's work prior to 1955 .
} 
Angelino's deed caused him to be invited to join the Honoured Society, otherwise known as the delinquent association, which exists to avenge young women who have been wronged, and thefts which have been committed unjustly (so they say), and any kind of bullying by the powerful. ${ }^{14}$

The inclusion of 'so they say' within this quotation is worth noting, implying as it does a level of distance between the narrator and the beliefs that he is relaying. The narrator, who introduces himself as Angelino's cousin, is himself a native of the same village, but explains that he now lives some distance away, perhaps reflecting Alvaro's own geographical distance from his homeland. There is thus a tension between the narrator's native familiarity with the culture he describes, and his current geographical (and cultural?) detachment from it. As I will indicate, however, where the honoured society is concerned, the void in attitudes implied by this initial 'so they say' is to a great extent closed by the narrator's descriptions of both the association itself and the cultural context in which it operates.

Angelino's invitation is prompted by the crime he committed in America: attempting to blow up his father's house, with his father and the old man's new lover inside it. However, the 'Ndrangheta in this story is no band of murderous, hard-hearted criminals. Instead, Alvaro depicts an association that is fundamentally tied to the values and customs of Calabrian peasant society, with a particularly strong emphasis on the importance of religion and family. The affinity between the honoured society and the community is demonstrated most clearly by the fact that Angelino's crime not only wins him the admiration of the mafia, but also that of the women of the village, who see his attempt to murder his father as an act in defence of his dead mother's honour and memory. The status that the deed confers upon him even grants Angelino the honour of accompanying the local bishop on his pastoral visits, and the narrator points out that the honoured society is religious.

Just as in many of Alvaro's other stories featuring Calabrian peasant protagonists, crime is presented in 'Angelino' as an entirely justifiable response to the injustices perpetrated by state authority, which has fostered the development of a distinct moral code. Indeed, as he describes embracing Angelino upon his return home, the narrator explicitly states that 'where we're from, someone isn't a criminal just because the law says they are. The morality of poor villages has nothing to do with the morality which exists on the basis of everything being fair'. ${ }^{15}$ Alvaro introduces the story by pragmatically explaining that for the young male inhabitants of this village, stealing is a sensible financial choice given the lack of other options, but emphasizes that this does not equate to a lack of scruples: the men may steal livestock from neighbouring villages, but they would not stoop to pickpocketing or burglary. This comfortable coexistence of crime within an accepted moral code is mirrored within the mafia, as evidenced by the criteria for selecting the capo of the organisation. In the story, the honoured society is unable to find a candidate with the necessary qualifications to fill the role (measured, reportedly, by the number of criminal convictions one holds).

\footnotetext{
14 "Una tale capacità ha procurato ad Angelino l'offerta di affiliarsi all'Onorata Società, altrimenti detta l'associazione a delinquere, che è costituita allo scopo di riparare i torti fatti alle ragazze e i furti subiti ingiustamente (cosi dicono), e ogni sorta di prepotenze da parte di chi è potente" (Alvaro 1955b, 487).

15 "da noi un criminale non è tale soltanto perché le leggi lo definiscono, la morale dei paesi poveri non ha niente da vedere con quanto è universalmente accettato col presupposto che tutto sia giusto." (Alvaro 1955b, 486).
} 
Despite his substantial criminal record, however, the incumbent boss, Macrino, is also presented as an embodiment of wholesome, traditional values; he is a family man who wants to retire so that he can spend more time with his children.

The antagonistic force in the story is not, as one would expect, the honoured society, but the morally corrosive influence of modern consumer capitalism. Angelino himself embodies this to an extent; the narrator informs us that Angelino 'had picked up the American obsession with business, and was dedicated to pursuing it. ${ }^{16}$ This leads him to set up a somewhat unsavoury enterprise; shipping in single foreign women unable to find a husband at home, and offering them as wives-cum-work-permits for young male villagers in search of a ticket to prosperity abroad. The honoured society thus seems aligned with a civilization and a way of life which are under threat, with Angelino perhaps representing a new, more ambitious breed of criminal.

Though 'Angelino' is unique among Alvaro's fiction in its explicit reference to the honoured society, in its critical portrayal of state authority, its idealisation of peasant culture, and its rationalisation of crime, it is very much typical of the author's depictions of Calabria elsewhere in his fiction, including the novel considered to be his masterpiece, Gente in Aspromonte (1930). While Alvaro's commitment to foregrounding the harsh conditions and desperate poverty in his representations of the region ensures that he is acknowledged as a realist, these representations are also considered to be characterized by their sentimentality and a tendency toward the romantic (De Bella 1973, 31-2; Piromalli 1977, 206-8). This extends in particular to Alvaro's depiction of Calabria's distinct values and traditions identified by Crupi (1992, 69-70) as 'the cult of the family, honour, blood, pride, total disregard for [state] authority, personal vengeance as an alternative to a lofty ideal of justice which has been found wanting. ${ }^{17}$ The justification and, to an extent, glorification of crime, are part of the author's insistence on the uniqueness of the values and worldview of the region, which he views as attributable to centuries of subjugation.

Published as part of a collection of short stories, the genre of 'Angelino' is easy to pin down as literary fiction, and it has not to my knowledge been cited in any sociological or historical works on the 'Ndrangheta ${ }^{18}$; though it is important to note that this has by no means prevented the extensive and undiscriminating inclusion of fiction in historical and sociological research on the 'Ndrangheta (see, in particular, Arlacchi's treatment of novels by Luca Asprea and Saverio Montalto (Arlacchi 2010)). The brief interrogation of the text offered above does, however, provide valuable context with which to interpret Alvaro's treatment of organised crime in his journalistic writing. As I have indicated, and will demonstrate below, the separation between fiction and journalistic writing is by no means clear or distinct in Alvaro's case, and an understanding of his literary portrayals of crime and Calabrian peasant culture is of substantial relevance to our interpretation of 'La fibbia'.

To highlight the potential ambiguity of the line between fact and fiction in Alvaro's journalistic writing, I will now briefly examine an article of his published several months before 'La fibbia', which also mentions the honoured society. Entitled 'I briganti' [the bandits], the text appeared in Corriere della Sera in May 1955, and describes a trip to Calabria undertaken by the narrator and a foreign female companion.

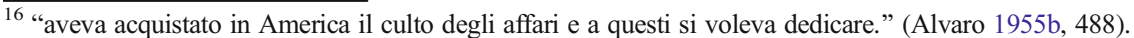

17 "il culto della famiglia, l'onore, il sangue, la fierezza, la disistima totale dei poteri, la vendetta privata dei torti come equivalente di un alto ideale di giustizia deluso" (Crupi 1992, 69-70).

${ }^{18}$ With the exception of Dickie $(2013,490)$ who acknowledges it in a footnote.
} 
Interestingly, although the narrator is himself Calabrian and refers to his own recollections of the organization later in the text, the 'onorata società' is initially introduced and explained to the pair through their local guide, Romeo; mirroring the distance between the narrator and the honoured society in 'Angelino'. When Romeo describes the essential function of the organisation, he suggests that its role is to 'put things in their rightful place', ${ }^{19}$ stressing that it sees no distinction between the powerful and the lowly in its pursuit of justice. He uses the example of 'forcing a seducer to marry the girl he would have abandoned', ${ }^{20}$ thus establishing a link between the honoured society and the enforcement of traditional values. Just as in 'Angelino', the text indicates the existence of a distinctly Calabrian moral code, which has evolved in the absence of the state; Romeo appears to have greater faith in the mafia's ability to mete out justice than he does in that of the official authorities, and when the organisation wrongs him in error (burning down ten of his olive trees) he calmly recounts that the mistake was honourably (and generously) rectified.

Through Romeo, the text also offers a benign, idealized vision of the 'Ndrangheta's past. He laments that attributes such as bravery and daring, which were once prized by the mafia, have since the Second World War given way to a new set of priorities based on wealth and acquisition: 'Money', he says, 'has taken precedence over courage and boldness. Positions of power [within the honoured society] have been taken over by people looking after their money, which leads to corruption... the corruption of the modern world, where money gets you everywhere'. ${ }^{21}$ The honoured society is thus again aligned with the preservation of treasured traditional values, while the antagonists of the piece are consumer capitalism and the distant authority of the state.

Alongside Romeo's opinions, the text also features a brief glimpse into the narrator's personal memories of the honoured society. As the narrator and his companion encounter the local capo in a café, the man's behaviour and mannerisms strike the narrator as familiar, and he recalls the languid manner and 'touch of decadence, 22 which indicate an individual's power and criminality. He remembers the physical appearance of members of the 'lower ranks', describing the colourful handkerchiefs they wore knotted around their necks, and also the swaggering gait of the 'higher ranks'. ${ }^{23}$ It is notable, however, that the narrator's recollections and observations are offered without any moral judgment, and none of the honoured society's activities (aside from the righting of wrongs) are acknowledged in any detail. As the article draws to a close, Romeo relays the fact that the new capo is a self-appointed, wealthy man, with the reader thus compelled to feel sympathetic nostalgia for a disappearing traditional institution.

Based on its content, although it is cited far less frequently than 'La fibbia', it would appear reasonable for the historian or sociologist to consider 'I briganti' an equally relevant, accurate source of data on the early 'Ndrangheta: the two texts are, after all, strikingly similar in many respects, published on the same page of the same newspaper, only

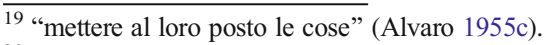

20 "costringere un seduttore a sposare la ragazza abbandonata." (Alvaro 1955c).

21 "Il denaro ebbe la prevalenza sul coraggio e la temerarietà. I posti di comando furono assunti da gente che doveva difendere il suo denaro; che poi ricorse alla corruzione [...] la corruzione del mondo moderno in cui tutto si ottiene col. denaro." (Alvaro 1955c).

22 "un che di decadente" (Alvaro 1955a).

23 "[i] più bassi" and "gli alti gradi" (Alvaro 1955a).
} 
four months apart. However, when it comes to assessing precisely what kind of document 'I briganti' is, there are some complications. A number of crucial contextual considerations raise significant questions regarding the genre (that is, the extent to which the text is fictional) and content of the text, which must be factored into any interpretation of its representation of the 'Ndrangheta. Given the similarity of the documents, these complications have significant implications for our understanding of 'La fibbia'.

First of all, it is not at all clear to the contemporary reader whether 'I briganti' is a straightforward account of an actual encounter - with Alvaro himself as the narrator - or a stylised piece, subject to a degree of artistic licence, as Ciconte acknowledges in his single reference to the article (Ciconte 1992, 240). ${ }^{24}$ An awareness of the conventions of Italian newspapers is of crucial importance in this regard. Just as in the case of 'La fibbia', the physical location of the text in the newspaper (the third page) is telling; immediately indicating that it may be a work of literature rather than journalism. Based on its narrative style and the ambiguity of the narrator, it is reasonable to assume that the text is actually a racconto or tale, which were a relatively frequent fixture on Italian terza pagine at the time of publication (Ceccuti 1978, 235). The extent to which the first-person observations and recollections contained within the text are those of the author, or those of an invented persona, is thus open to question, and the inclusion of a foreign female companion evokes earlier nineteenth century picturesque literary representations of Sicily, particularly the work of Giovanni Verga (see Moe 2002).

A second key consideration relates to the content of the text, which appears to combine factual and fictional elements. As Dickie $(2013,490)$ notes, 'I briganti' features a description of the mafia's difficulty electing a 'capo della provincia' [regional boss] in 1948, which mirrors a very similar event in the story 'Angelino'. Furthermore, Alvaro's posthumously published diaries include a number of brief entries from 1952 and 1953 in note form, which appear to contain the seeds for many of the ideas and events described in 'Angelino, 'I briganti', and 'La fibbia', but with only vague indications as to the sources of the information. One, from 1953, includes references to the shift in the organisation's priorities away from its traditional values and towards profit, a description of the clothing preferred by affiliates, and the specific revelation that following the failure to elect a capo in 1948, the organisation was split into three distinct zones (Alvaro 1959, 126). ${ }^{25}$ Within the entry, Alvaro mentions 'childhood memories', but also makes reference to a conversation with an unknown individual, who clearly forms the basis for Romeo - a man who regards the members of the honoured society as agents of social justice, having been handsomely repaid when his ten olive trees were burned by mistake.

The note format of this diary entry, which is characterised by the absence of fully formed sentences and paragraphs, hinders interpretation, and the lack of context provided by the author is frustrating. It seems clear, however, from this evidence that the article 'I briganti' is a stylised development of a story told to Alvaro by an unnamed source several years previously. Furthermore, given that various different components of the story 'Angelino' are spread across a number of different entries in the diary, it is not too great a stretch to infer that the author developed ideas for short stories in much the same manner as he did for his

\footnotetext{
${ }^{24}$ While Ciconte concedes that Alvaro's interlocutor may or may not be based on a real figure, this does not detract from his willingness to quote the character, nor to elaborate upon the validity of the point it is making.

${ }^{25}$ N.B. The latter point is supported by judicial evidence from the same period. See Ciconte (1992, 5-215); Dickie (2013, 165-196).
} 
journalistic articles. Crucially, however, with the exception of Dickie (2013), none of the scholars citing either 'I briganti' or 'La fibbia' acknowledge the existence of this diary material, despite its clear implications for our reading and understanding of the articles. Nor, furthermore, do any make reference to the Italian publishing context or the conventions of the terza pagina; nor Alvaro's well-documented tendency to romanticise in his literary representations of Calabria elsewhere.

Even regular newspaper reports, ostensibly concerned with reporting the facts of an event, should be approached with caution by historians and sociologists. Even if no explicit opinion on events is offered by the author, reports are subject to a range of political, social and cultural biases, which are manifested by processes including the foregrounding of certain features of a story at the expense of others, and the use of language, among others (see Capecchi and Livolsi 1971). As the analysis above has indicated, however, 'I briganti' and 'La fibbia' are examples of a distinct type of newspaper text, with a clear and distinct narrative voice and a much greater potential for authorial agenda, as well as a marked tendency to combine the author's own experiences with borrowed ones, and even, potentially, elements of fiction. Further investigation is required into the diversity of Italian newspaper texts as sources, and the differing ways in which they are interpreted by contemporary audiences and historians, particularly in the context of organised crime. For now, it must suffice to point out that the term 'newspaper article' in socio-historical research on the mafia appears to encompass a range of differing genres, and that this genre ambiguity, and its impact, are too rarely acknowledged by researchers. This includes 'La fibbia', which is cited simply as an 'article' (if its genre is acknowledged at all) by the majority of the scholars to whom I have referred (including Ciconte 1992; Gratteri and Nicaso 2010; Gratteri and Nicaso 2012), but identified by Crupi $(1992,69)$ as a 'racconto-saggio' (literally translated as 'story-essay'), which introduces much greater room for artistic license on the part of the author.

\section{Reinterpreting 'La fibbia'}

It is clear, based on the factors outlined above, that the tendency of historians and sociologists to tacitly assume the portrayal of the 'Ndrangheta within 'la Fibbia' to be a straightforward reflection of historical fact is flawed, and potentially misleading. However, the aim of this paper is not to discount the value of this text, and others like it, as sociohistorical sources. Instead, I advocate a re-interpretation of the representations of the 'Ndrangheta within these texts, which, rather than accepting the portrayals at face value, analyses the specific vision of the mafia which they offer, and considers their relationship with previous and subsequent representations. They might be interpreted as what Neumann $(2010,334)$ has referred to as 'fictions of memory'; contributing to the 'negotiation of cultural memory' by offering an 'imaginative (re)construction of the past in response to current needs.'

Based on the analysis above, it is possible to trace recurring themes in Alvaro's treatment of organised crime; particularly his depiction of the differing meanings of justice, and his nostalgia for traditional peasant culture in his home region, which lead him to paint the 'Ndrangheta in a sympathetic light - an observation which is notable for its absence in the work of the vast majority of scholars who cite the article, and runs counter to the modern perception of the author as entirely critical of the mafia. In 'La fibbia', it is notable that 
Alvaro holds back from criticising the 'Ndrangheta in any explicit terms. Criticism in the text is reserved almost entirely for the state, and the existence of the 'Ndrangheta is thus tacitly justified, mirroring the approach to crime we have seen elsewhere in Alvaro's work. In the article, he makes the entirely valid argument that the 'Ndrangheta is a result of decades of negligence by the authorities, and that this has created conditions which have allowed positions of responsibility to be assumed by those able to win them through violence and intimidation: 'When a society offers few, or no, opportunities for upward mobility, inspiring fear in others becomes a means of achieving status' (Alvaro 1955a). ${ }^{26}$

However, the violence perpetrated by the 'Ndrangheta receives little acknowledgment beyond this in Alvaro's text, and although the author recalls his own father suffering a blow to the head from one of the affiliates on one occasion while walking home at night, the incident is described in oddly detached terms, removed of any fear or menace. Indeed, the author displays a marked reticence to identify mafiosi as violent killers, with individual, human victims. In 'La fibbia', Alvaro consistently plays down the threat posed by the 'Ndrangheta, positioning it as an accepted part of society which represents no danger to the majority of people: speaking of the mafiosi, Alvaro states that "nobody in the village considered them people to avoid' (Alvaro 1955a). ${ }^{27}$ The author seems determined to normalise and neutralise their menace, and even indicates that the violence which does occur is circumscribed within the organisation itself, stating that 'they killed one another for breaches of omertà, but that was their business alone'. ${ }^{28}$ In doing so, however, Alvaro exposes a contradiction which reflects the darker reality he appears unwilling to confront. If violence and intimidation really were confined to the mafia itself, then who were the people that the mafiosi were intimidating - by Alvaro's own admission - as a means to achieving status? The simple fact is that innocent people were frequently murdered, brutalised, and extorted by the organisation during this earlier period of its history, as a substantial weight of evidence unambiguously proves (see Ciconte 1992; Dickie 2013).

Alvaro does attempt to deal with this contradiction to a degree by once again shifting the focus of his criticism, with the implication that the mafia which is active in Calabria in 1955 represents a distorted, modern incarnation of a traditional phenomenon with a quite separate ethos. While the distinction between an old and a new mafia is less pronounced than in 'I briganti' or 'Angelino', both of which identify the modern preoccupation with accumulating wealth as a corrupting influence on an organisation which traditionally upheld the values of peasant society, traces of this division are visible in 'La fibbia'. For example, the article states that only in recent years has the organisation concerned itself with infiltrating political and economic interests. For Crupi (1992, 65), 'La fibbia' thus represents Alvaro's lament of the transformation of the benign 'Fibbia' of old into a new, malignant 'mafia' with an altered set of priorities. ${ }^{29}$ Contextualised with 'I briganti' and 'Angelino', it seems reasonable to conclude that Alvaro was keen to emphasise this transformation, or more precisely, degeneration of the organisation, particularly in light of his repeated insistence in his diaries

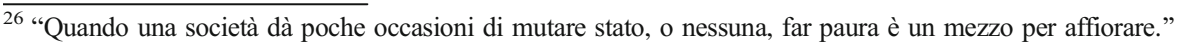
(Alvaro 1955a).

27 "Nessuno in paese li considerava gente da evitare"(Alvaro 1955a).

28 "Si assassinavano tra loro per gli strappi all'omertà, ed erano affari loro" (Alvaro 1955a).

${ }^{29}$ It is important to acknowledge that this distinction between the two names is Crupi's, not Alvaro's. As we have seen, the author uses a variety of names with reference to the 'Ndrangheta, placing the terms 'fibbia' and 'mafia' side by side as equivalents.
} 
that American films and consumerist culture were responsible for the development of the 'gangster' mentality (Alvaro 1959 171; 208).

In all the texts analysed above, Alvaro exhibits a clear tendency to minimise any implication of the harm done by the honoured society, and instead construct the myth of an association which upholds traditional Calabrian values, from the family-man-cummultiple convict mafia boss in 'Angelino', to the defenders of female virtue described by Romeo in 'I briganti'. Alvaro's honoured society, and with it all the values and traditions which he holds so dear, has been transformed into a 'mafia' via the catalysts of profit, progress, and a power vacuum created by the state. In condemning the 'Ndrangheta in 'La fibbia', Alvaro condemns only this new manifestation of the organisation, and reserves the bulk of his criticism for the state which has allowed it to proliferate and infiltrate into positions of authority. Meanwhile, he constructs a myth of an old honoured society which avoids confronting the violent reality of the organisation's past, in an extension of the romanticised portraits of crime which we have observed elsewhere in his writing. ${ }^{30}$

\section{Conclusions}

In 'La fibbia', 'Angelino', and 'I briganti', Alvaro clearly implies that the mafia which is active in Calabria in 1955 represents the beginnings of a corrupted, modern incarnation of an honoured society which once enjoyed the consensus of the Calabrian people, embodying their values and traditions. While there are obvious elements of truth in his identification of the socio-economic drivers for mafia recruitment and proliferation, and the changes which were beginning in the middle of the twentieth century, in his portrayals of the early 'Ndrangheta, Alvaro constructs a myth which glosses over the violent reality. The author's dogged refusal to acknowledge the inherent violence of the early 'Ndrangheta and his firm positioning of blame with the Italian state can be located within a wider trend of defensiveness in Calabrian regional journalism in the 1950s, in response to the negative press stereotyping produced by the Marzano Operation (Ciconte 1992, 287-288) - a phenomenon which itself deserves further investigation. There is an insistence on the specificity, and, to an extent, the superiority $^{31}$ of the Calabrian context in Alvaro's writing which recalls

\footnotetext{
${ }^{30}$ Lupo $(1993,23)$ refers to this mythologised construction of the past as a strategy adopted by the Sicilian mafia, which he says has historically appropriated cultural codes and expressed an ideology 'to create consensus on the outside and compactness on the inside' ["creare consenso all'esterno e compattezza all'interno"].

${ }^{31}$ N.B. Dickie $(2013,83)$ posits that Alvaro's acknowledgment of the 'Ndrangheta in 1955 constituted a recovery of memory, in light of an article published by the author in 1949 which declared Calabria to be free of "criminal societies in imitation of the mafia' (translation by Dickie, Ibid.). My own interpretation of this 1949 article is that it represents Alvaro's consistent belief in the uniqueness (and superiority) of the Calabrian honoured society, which he identifies as firmly distinct from the Sicilian mafia. This interpretation is supported by an account of a meeting with Alvaro written by the author Saverio Strati, in which Alvaro is reported to have highlighted the nobility and chivalry of the Calabrian mafia at the expensive of its Sicilian cousin (Strati 1978, 107-108). Alvaro's comments in this exchange indicate firmly that he viewed the Calabrian mafia as an entity of superior moral character, making his comments in 1949 a matter more of a semantic distinction between the Sicilian mafia and the "Ndrangheta, than a denial of the existence of organised crime in his native region.
} 
Sicilianismo, and more research is required into what we might term this 'calabresismo', and its impact on public and official responses to the organisation. By presenting a benign construction of the 'Ndrangheta's past in his 1955 writings on the organisation, Alvaro creates an example of Neumann's 'fictions of memory'; disseminating an idealised construction of the past in response to the stimulus of perceived attacks on his home region in the national press.

Further, through his textual representations of the organisation, Alvaro actively contributes to subsequent representations and perceptions of Calabrian organised crime, as Neumann $(2010,341)$ explains: 'Because literature is interwoven with other systems of memory culture, it not only draws on pre-existing discourse systems but is also in a position to productively influence these systems.' This surely extends to the academics who cite his work, as well as to the perceptions of the public, and to the authorities. The enormous impact of cultural products, particularly films, on perceptions of Italian organized crime is well acknowledged, particularly with regard to the Sicilian mafia, but there is a great deal more to be explored with regard to the Calabrian context.

I hope that Alvaro has proved a convincing case study for the importance of a thorough and critical approach to literary and journalistic sources, if only by indicating how failing to interrogate them in detail or within context can significantly impact our understanding of their message. The complex, sometimes ambiguous nature of Italian terza pagina journalistic texts is of particular concern, and has clear implications for the interpretation of these texts as historical and sociological sources. The primary goal of this article, however, is not to undermine the usefulness of literary or journalistic texts, nor to think of them purely in terms of their usefulness as sources of socio-historical data. It is hoped that this paper has indicated that while literary and textual representations of the 'Ndrangheta's past cannot and should not be considered as tacitly historically accurate, texts like 'La fibbia', which are capable of both reflecting and at the same time shaping public opinion, can teach us a great deal about perceptions of Calabrian organised crime within its host communities, and raise interesting questions related to identity and blame.

These representations must be analysed in their own right, in order to gain a greater understanding of the social and cultural factors which might lie behind their specific portrayal of the organised crime phenomenon. The myth of the 'Ndrangheta's benevolent past still persists in some corners of Calabria, and has historically been used by the organisation to its advantage. I believe that a more complete integration of cultural products into research on the 'Ndrangheta can shed a great deal of light on this, and many other questions in this field, including analyses of how knowledge of criminal history is constructed.

Compliance with ethical standards This study is based on the doctoral work of the author, which is funded by the Arts and Humanities Research Council.

Conflict of interest The author declares that she has no conflict of interest.

Ethical approval This article does not contain any studies with human participants or animals performed by any of the authors. 
Open Access This article is distributed under the terms of the Creative Commons Attribution 4.0 International License (http://creativecommons.org/licenses/by/4.0/), which permits unrestricted use, distribution, and reproduction in any medium, provided you give appropriate credit to the original author(s) and the source, provide a link to the Creative Commons license, and indicate if changes were made.

\section{References}

Alvaro C (1930) Gente in Aspromonte. Le Monnier, Florence

Alvaro C (1955a) La fibbia. Corriere della Sera, 17 September.

Alvaro C (1955b) Angelino. In: Settantacinque racconti. Bompiani, Milan

Alvaro C (1955c) I briganti. Corriere della Sera, 18 May

Alvaro C (1959) Ultimo diario. Bompiani, Milan

Arlacchi P (1983) La mafia imprenditrice. Il Mulino, Bologna

Arlacchi P (2010) La mafia imprenditrice: Dalla Calabria al centro dell'inferno. Il Saggiatore Tascabili, Milan

Badolati F (2014) Mamma 'ndrangheta. Pellegrini Editore, Cosenza

Blok A (1974) The Mafia of a Sicilian village, 1860-1960: A study of violent peasant entrepreneurs. Blackwell, Oxford

Capecchi V, Livolsi M (1971) La stampa quotidiana in Italia. Bompiani, Milan

Ceccuti C (1978) Il quotidiano ieri e oggi. Uniedit, Florence

Ciconte E (1992) 'Ndrangheta: dall'unita a oggi. Bari: Laterza.

Crupi P (1992) L'anomalia selvaggia: camorra, piciotteria e 'ndrangheta nella letteratura calabrese del Novecento. Sellerio, Palermo

Crupi P (2013) La 'ndrangheta nella letteratura calabrese. Pellegrini, Cosenza

De Bella N (1973) Corrado Alvaro. Editrice Ciranna, Rome

Di Girolamo G (2012) Cosa grigia. Una nuova mafia invisibile all'assalto dell'Italia. Il Saggiatore, Milan

Di Ronco A, Lavorgna A (2016) Changing Representations of Organised Crime in the Italian Press. Trends in Organised Crime, pp. 1-23. Web.

Dickie J (1999) Darkest Italy: The Nation and Stereotypes of the Mezzogiorno, 1860-1900. Palgrave, New York

Dickie J (2012) Mafia Brotherhoods. Sceptre, London

Dickie J (2013) Mafia Republic. Sceptre, London

Erll A (2010) Literature, Film, and the Mediality of Cultural Memory. In: Erll A, Nünning A (eds) A Companion to Cultural Memory Studies, Berlin: De Gruyter, vol 2010, pp. 389-398

Europol, 2013. Threat assessment: Italian organised crime. The Hague: Europol. Available at: https://www. europol.europa.eu/content/threat-assessment-italian-organised-crime [Accessed 30 August 2015]

Farrell J (1995) Leonardo Sciascia. Edinburgh University Press, Edinurgh

Gratteri N, Nicaso A (2010) Fratelli di sangue. Pellegrini, Cosenza

Gratteri N, Nicaso A (2012) Dire e non dire. Mondadori, Milan

Gribaudi G (1996) Images of the South. In: Forgacs D, Lumley R (eds) Italian Cultural Studies: An Introduction. Oxford University Press, Oxford

Hess H (1970) Mafia. Tubingen: Mohr (published in Italian in 1973. Laterza, Rome-Bari

Lupo S (1993) Storia della mafia. Donzelli, Rome

Moe N (2002) The view from Vesuvius: Italian culture and the southern question. Berkeley: University of California Press.

Murialdi P (1998) Il giornale. Mulino, Bologna

Neumann B (2010) The Literary Representation of Memory. In: Erll A, Nünning A (eds) A Companion to Cultural Memory Studies, Berlin: De Gruyter, vol 2010, pp. 333-343

Nicaso A (2007) Senza onore: Antologia di testi letterari sulla 'ndrangheta. Cosenza: Pellegrini

Paoli L (2003) Mafia Brotherhoods. Oxford University Press, Oxford

Piromalli A (1977) La letteratura calabrese. Guida Editori, Naples

Shaw K (2012) Mining the Meaning: Cultural Representations of the 1984-5 UK Miners' Strike. Cambridge Scholars, Newcastle

Strati S (1978) 'Un incontro con Alvaro', in Cingari, G, La 'politica' di Corrado Alvaro. Ierici, Rome

Truzzolillo F (2011) 'The 'Ndrangheta: The Current State of Historical Research', Modern Italy, 16:3 (2011), $363-383$ 
Truzzolillo F (2013) "Criminale" e "Gran Criminale". La struttura unitaria e verticistica della "ndrangheta delle origini. Meridiana, 77, special issue on 'In nome del popolo sovrano', 203-232

Welzer H (2010) Communicative Memory. In: Erll A, Nünning A (eds) A Companion to Cultural Memory Studies, Berlin: De Gruyter, vol 2010, pp. 285-298 